\title{
Hva gjør hæren av ansatte i helsevesenet?
}

\author{
Hvor mange helsearbeidere må det til for å helbrede én pasient? I dagens situasjon er det \\ riktigst å gi et flytende svar: Flere og flere!
}

\begin{abstract}
Pasienten vil helst forholde seg til én lege, mens utviklingen har gått i motsatt retning. Legene og sykepleierne blir bare mer og mer spesialiserte, og dessuten har de fått selskap i Helsevesenet av en rekke andre profesjoner med like høy grad av spesialisering. På et stort, moderne regionsykehus kan det være flere hundre ulike profesjoner, fra sjåfør, dataekspert og renholdskonsulent til prest og konditor. Samtlige lever både for og av pasienten.
\end{abstract}

For 30 år siden tok nevrologen Arve Lønnum (1911-88) for seg dette fenomenet, og han visste hva han skrev om. Lønnum var utdannet lege fra Sverige i 1945, og etter allsidig tjeneste innen nevrologi, nevrokirurgi og nevrofysiologi og doktorgrad fra Oslo ble han overlege i nevrologi på daværende Sentralsykehuset i Akershus på Lørenskog (nåværende Ahus) og dosent ved Universitetet i Oslo. I tillegg til sitt vanlige arbeid var han aktiv med å løse helseproblemer hos tidligere krigsfanger, og han hadde en rekke offentlige tillitsverv. Dessuten var han politisk aktiv og satt som formann i Fremskrittspartiet 1975-78. Gjennom arbeidet på store sykehus og innen helsevesenet generelt hadde han sett hvordan staben ekspanderte. Når de mange helsearbeiderne ikke klarte å helbrede pasienten, skapte de seg i stedet en sikker levevei ved å ta hånd om kronisk sykdom. Samlet utgjorde de det han kalte helselauget, og dette lauget tok stadig på seg nye oppgaver. På de tider gikk det ganske friskt for seg i profesjonskampen innen helse- vesenet, for de ble etter hvert mange om beinet - eller rettere sagt om pasienten. Her skriver han lakonisk: «lkke alle laugsmedlemmene er like glade i hverandre, men dog enige om at de er uunnværlige, og at betalingen bør være god, og dertil stadig øke.»

I årene siden Lønnum døde har utviklingen gått drastisk videre. Ingen vet hvor den vil ende, for hver gang et helseproblem blir løst, kommer det nye oppgaver. De blir både mer kostbare og mer personalkrevende. Og alt dette må administreres. Heldigvis har det også skjedd en annen og like dramatisk utvikling enn bare personaløkning: Samarbeid og logistikk har utviklet seg like raskt, og nye, avanserte behandlingsformer og høyteknologi har gitt betydelige fremskritt og til dels lavere utgifter. Økte kostnader og besparelser går derfor hånd i hånd. Kanskje er vi på rett vei allikevel? Men etter en hel generasjon med utvikling er Lønnums profetiske artikkel og advarsler likevel verdt å lese.

\section{Ole Didrik Lærum}

ole.laerum@gades.uib.no

Ole Didrik Lærum (f. 1940) er professor (adj.) ved Københavns Universitet og professor emeritus ved Gades Institutt, Universitetet i Bergen.

\section{Helselauget - et interessant sosiologisk fenomen}

Arve Lønnum Helselauget - et interessant sosiologisk fenomen. Nord Med 1982; 97: 90-1.

Etter at mange fremragende helseeksperter har kunnet fastslå at sykdom er mangel på fullt velbefinnende, er det lett å forstå at folk føler seg sykere og sykere etter hvert som denne sannhet avleires i deres bevissthet.

Men så viselig er samfunnet blitt innrettet at det går an å leve av sykdom. Dette kan skje ved egen sykdom, og pengestøtte for denne. Men det kan også skje ved andres sykdom. Noen særlig innbringende levevei var ikke dette siste, så lenge folk selv måtte betale for hjelpen. Da ville de ut med noen kroner bare hvis livet sto på spill, og knapt nok da.

Annerledes etter at samfunnet overtok og organiserte, ikke alene behovet, men også hjelpen. Først da ble det klart hvor mang- slungen hjelp de syke egentlig trenger, og hvor stort apparat som er nødvendig for å gi den. Legene trenger ved sin side farmasøyter, tannleger, sykepleiere, hjelpepleiere, fysioterapeuter, psykoterapeuter, sosionomer, teknikere av mange slag, kontorfunksjonærer og administratorer. Sist, men ikke minst, trenges egne organer til å styre alle disse hjelpere og til å avlønne dem. Så rart det enn høres, vil de nemlig ha betaling. Nestekjærligheten er, som fotballen, blitt profesjonell, og utøverne knyttet sammen i et eneste stort fellesskap eller laugsystem, av noen kalt, helsebyråkratiet, fordi hjelp fortrinnsvis blir gitt i kontortiden.

Ikke alle laugsmedlemmene er like glade $i$ hverandre, men dog enige om at alle er uunnværlige, og at betalingen bør være god, og dertil stadig øke. Lauget, som er herre over liv og død, vet at folk alltid lar seg skremme til å betale.

\section{Stadig nye arbeidsoppgaver}

Blandt de absolutt sikre ting i verden er derfor at utgiftene til dette laugsystem vil øke. Dertil medvirker også systemets selvformerende evne. Det skaper seg nemlig selv stadig nye arbeidsoppgaver, dels ved å registrere hittil ikke erkjent elendighet, dels ved å oppdage nye sykdommer, som i sin tur krever nye former for behandling.

Meget sinnrik er oppfinnelsen av teamet, det system altså at flere laugs-medlemmer kan gå sammen om å leve av en og samme 
pasient. Ganske spesielt har lauget tjent på avskaffelsen av de akutte sykdommer som så mange døde av tidligere. En slik sykdom gav inntekt bare en gang, på samme måte som en hulltann som ble trukket. Etter innføring av plombering kan imidlertid tannlegen i våre dager tjene flere ganger på en og samme tann. Ved å spesialisere seg på kroniske sykdommer har lauget konsolidert sin stilling ytterligere, idet der tas sikte på å holde liv i folk, akkurat så pass at de ikke dør, men ikke så pass at de ikke lenger trenger hjelp.

Det sier seg selv at slitet med alt dette har medført store påkjenninger for laugets medlemmer, så store at det er blitt klart for alle at det er dem det egentlig er synd på, ikke pasientene, som i gamle dager.

Samfunnet har tatt konsekvensen av dette og lagt stadig større vekt på å omgjøre helseinstitusjonene til velferdscentraler for de ansatte. Disse må skånes for lang arbeidstid og unødig stress som kan ta knekken på selv de sterkeste.

Hvis vi bryter sammen, sier laugsmedlemmene, vil det bli riktig ille for pasientene. Det må tross alt være bedre å få hjelp på formiddagen, og i ukens fire første dager, enn ingen hjelp å få i det hele tatt.

Det har bare én liten ulempe, dette fortreffelige system. Det er blitt så dyrt at endog velferdsstatens politikere er blitt alvorlig bekymret, og da vil noen hver skjønne at saken er alvorlig.

Vi blir dog trøstet med at helselauget skal få sitt, om nødvendig med penger lånt fra utlandet.

Helselaugets medlemmer kan derfor se fremtiden fortrøstningsfullt i møte. De banale økonomiske lover som gjelder for all annen virksomhet i samfunnet, gjelder ikke for dem.

Men det hender at helselauget blir bedt om å avlegge regnskap for sin virksomhet og svare på det meget betimelige spørsmål: Hvilken nytte gjør dere egentlig?

Svaret har vært temmelig nedslående. Helselaugets innsats for folkehelsen må anses som ubetydelig. Den har ingen innflytelse på tidens frustrerte ungdom, på den økende skare uføretrygdede og førtidspensjonister, på de stadig flere neurotikere og narkotikamisbrukere.

\section{Det syke samfunn}

Men dette er da ikke vår skyld, sier laugsmedlemmene, dette er samfunnets skyld. Det er samfunnet vi må gjøre noe med. Dermed er det duket for en ny æra i helselaugets historie, behandlingen av det syke
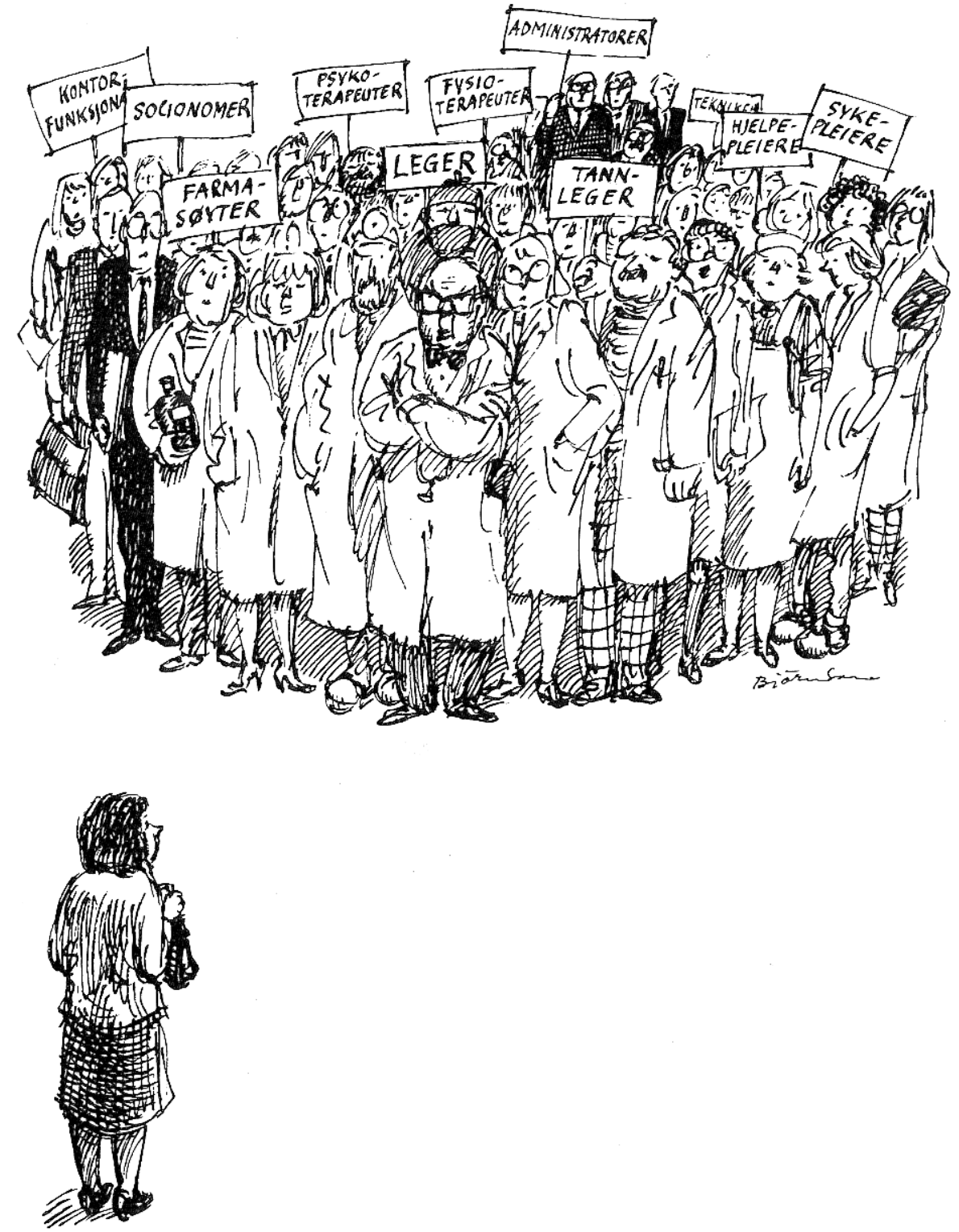

Meget sinnrik er oppfinnelsen av teamet, det system altså at flere laugsmedlemmer kan gå sammen om å leve av en og samme pasient. Tegning Sven Björnson, Sverige

samfunn. Sosialmedisinen rykker inn på arenaen. Dette er kronen på verket. Helselaugets makt er sikret for godt.

Dets medlemmer kan fortsette sin suverene lek innenfor fagets lekegrind, der de går rundt og vet alt som bare de kan vite som har tilbragt sitt liv med å beskue sin egen navle.

Vi har altså for oss en meget interessant utvikling. Først lanseres et helsebegrep som gjør alle til syke mennesker.

Deretter overlates til samfunnet å ta seg av dette. Helselauget organiseres, profesjonaliseres, utvider arbeidsfeltet, avskaffer lite inntektsgivende sykdommer og sikrer sine medlemmer varig sysselsetting gjennom innføring af teamet.

Stress motvirkes gjennom henleggelse av arbeidet til formiddagstimene og omgjøring av helseinstitusjonene til velferdsanstalter for de ansatte.

Systemet blir så dyrt at samfunnsøkonomien sprekker. Laugsmedlemmene parerer ubehagelige spørsmål ved å rette søkelyset mot samfunnet som er sykt og må behandles. Helselauget forskanser seg bak de 100 helseprofesjoners ugjennomtrengelige murer.

Samfunnet forblir like sykt, hvilket selvsagt også var meningen. Den dag samfunnet får et nytt helsebegrep og friskner til, vil jo helselaugets makt være brutt og dets medlemmer nødt til å se seg om etter annet og mer nyttig arbeid enn å skape fullt fysisk og psykisk velbefinnende hos borgere av en verden som alltid har vært, og alltid vil være, en jammerdal. Om den var noe annet, hvilken grunn skulle vi så ha til å lengte etter et bedre liv i det hinsidige? 